International Journal of Social Science And Human Research

ISSN(print): 2644-0679, ISSN(online): 2644-0695

Volume 05 Issue 02 February 2022

DOI: 10.47191/ijsshr/v5-i2-08, Impact factor-5.586

Page No: 432-439

\title{
Smart Policing of Madhy Pradesh Dial-100 (Special reference to Sagar District)
}

\author{
Rupesh Kumar Upadhyay ${ }^{1}$, R.K.S. Chauhan ${ }^{2}$, Rameshwar Singh Yadav ${ }^{3}$ \\ ${ }^{1}$ Research Scholar (Criminology) Department of Criminology and Forensic Science Dr. Harisingh Gour University, \\ ${ }^{2}$ Sub-Inspector of Police (Radio), Sagar, M.P. \\ ${ }^{3}$ Add. Superintendent of Police, Sagar, M.P.
}

\begin{abstract}
Police and public depend on each other; without one another can't survive. Madhya Pradesh became India's first state for using this effective modern technology for crime prevention \& providing emergency help to victim at crime scene. It got tag of India's first \& largest integrated police emergency response service. This study explores the system, strategy and functional techniques of dial-100 at Sagar district of Madhya Pradesh state. It also analysis about cases reported through dial- 100 as road accident, children related, women related crime body etc. This project stands to police having GPS, GIS, and MDT at victim's door within a little minute at one call or miscall. The police are one of the most visible and recognizable institution in modern society. Dial-100 team works also as surveillance, spot counseling and vigilance and FRV works as surveillance vehicle through event and round events. The team controls crime and help victims in the district with 26 FRV over 2378458 populations and one FRV covers 91479.15 populations. This smart policing not only reduces crime but also puts an example of humanity in society.
\end{abstract}

KEY WORDS: M.P. Dial-100, victim, dpcr, spcr, frv.

\section{GENERAL INTRODUCTION:}

Embracing the instinct of patriotism and public service the Madhya Pradesh police started 'Dial-100' scheme with the purpose of rushing immediate help to the meager suffering soul. The present study is an abridged portion of the dissertation made on 'Dial-100' in the Sagar district during M.P. Police Internship, 2018. This study is based on the response received by the chief of the police stations, personal, first response vehicle staff as well as the incharge of District Police Control Room (DPCR) and also on the response of the of the people whom help and support was reached. M.P. Dial-100 i

The first and largest unified (integrated) emergency police response service of India. This service is reached just on dialing number100. If someone miscalls also, the one of call taker call back within a minute. Exploring this service and strong relationship with public the system launches Dial-100 apps, can be download from google play store and whatsapp number +917587600100 .

\section{THE OLD SERVICE OF 100 DIAL IN MADHYA PRADESH:}

'Police for safety, safety for development and development for the people'- the saying can bring solution to many doubts without any extra and an elaborate explanation. In order to maintain law and order there is the post of constable on the base level and that of Director General of Police on the top most level. For effective and skilful running of the police management, there are mainly two branches, first law and order and the other tale-communication department which conducts radio, radar, wireless etc. A toll-free number i.e.'100' has been enforced with the purpose of making the condition of law \& order good from 'ordinary' and 'fine' from 'good'. This facility has been provided in public interest. Number ' 100 ' could be dialed to avail of help from the round the clock active police. There used to be attached problems to the old system some time number' 100 ' could not be connected, the problem in the network, failure in proper communication, lack of knowledge of the mood of the police personal on duty; sometimes the police person having returned tired after duty on a certain spot of event could not be in a smooth state of mind to be easily convinced. As a result of failure in police -victim contact on the phone, the feeling of frustration and distrust on the police used to rise in the mind of the sufferer. The following were the main problems related to the old ' 100 ' system-

- Want of trained police staff/ the phone remaining unpicked up.

- Scarcity of police staff, observer and police vehicles.

- Lack of technically trained and skilled staff and monitoring.

- Want of provision of feedback by the victim for excellence in work. 


\section{Smart Policing of Madhy Pradesh Dial-100 (Special reference to Sagar District)}

\section{MODERN 'DIAL-100': DIAL-100 CALL THE POLICE:}

Mr. Anvesh Manglam, Additional Director General of Police (T.C) M.P. had long ago anticipated the requirement of police personnel in the old dial-100 system and the future needs in the age of globalization and the internet. As a result on Nov. 01, 2015, the day of the Foundation of Madhya Pradesh C.M. Mr. Shiva Raj Singh Chauhan started from the Bhopal, the state capital the dial100 scheme at once in seven districts. Afterwards it became effective in the entire district. In order to better

the performance of the dial-100 system, there are control rooms on two levels - the State Control- room, Police Headquarter (Telecommunication), Bhopal which receives nearly 25 to 26 thousand phone calls each day and the second the Dial-100 control room in each control room of each district. Under this establishment phone call on number 100 receives a hundred percent response; and the problem is dealt with till the satisfaction of the caller.

\section{REVIEW OF THE LITERATURE:}

The Economic Times (2015) writes that ADG (TC) of M.P. Police Mr. Anvesh Mangalam, said that one of the priorities of dial100 is to provide quality service to people and win their confidence. On behalf of this under the system a first information report (FIR) will be registered on the spot. If police do not register the FIR, they are going to state a valid reason for it.

According to dailypioneer.com (2015), Referring to dial-100 service the Chief Minister said that it would enhance trust between police and people and send message to criminals that police is alert and can reach incident spot immediately. According to the same all police stations are being hitch with electronic mapping who will solve the problems at one call on 100 number. If someone feels any problems any time, should just call on 100 number. In trouble time should not be afraid because of this offender gets chance to crime. https://www.youtube.com/watch?v=QtSC-CY9Xx4 (2018).

\section{OBJECTIVES:}

1. To study the system and management of Dial-100.

2. To analyses reported event and problem and solution of Dial-100 in Sagar district.

\section{METHODOLOGY:}

The study is based on secondary data as well as primary data in the form of video recording. The convenience sampling have been used for data. In this study all data have been collected from dial- 100 dashboard in dial-100 control room of Sagar district. Total sample size i.e. case called event number is 7292 during one month from 01 June to 01 July, 2018. These events are reported phone call at 100 number.

\section{A VIEW OF THE MANAGEMENT OF M.P.DIAL-100: MAIN FUNCTIONAL BODY OF DIAL-100 SERVICE-}

\section{Call taker in call center at SPCR.}

Dispatcher in call center at SPCR.

II. FRV team.

III. Dial-100 control room in DPCR.

IV. SPOC of police station(s) and Police Office(s) in District.

1. At present in all the fifty one districts of Madhya Pradesh one thousand ultramodern vehicles have been developed under the Dial-100 scheme; which are kept ready to rush to the spot of incident as soon as information is received (The maximum time limit of their approach is five minutes in the urban area and thirty minutes in the rural section.

2. The ultramodern vehicle which is named First Response Vehicle (FRV) is available under every police station of each district.

3. In the Dial-100 State Police Control Room (SPCR) an ultramodern call center with 110 seats has been set up, which is equipped with facilities like CAD, GPS, GIS and Voice log. One who calls is called a 'Caller'. To get informed with the caller's problems forthwith one hundred twenty-five telephone lines are dedicated twenty four hours to receive the call. Simultaneously they are all in contact with the respective DPCR and with the staff of the FRV.

\section{DISTRICT SAGAR AND 'DIAL-100':}

Situated in the heart of the state of Madhya Pradesh, District Sagar is located between 23 deg 10' and 24 deg $27^{\prime}$ North latitude and between $78 \mathrm{deg} 4$ ' and $79 \mathrm{deg} 21^{\prime}$ 'East longitude. This area falls under Bundelkhand region. Its length from East to West is $169 \mathrm{~km}$ and its total area is 10252 square $\mathrm{km}$. According to the 2001 population survey its total population is 2378458 consisting of 1256257 male and 1122201 female. Out of total 35 Thanas 10 Police Thanas come under the Sagar sector, of which 07 'Law \& Order' Thanas under which there are 08 active FRV and at the District level there is 26 FRV. Thus, we found that one FRV controls 91479.15 population which contains. In order to properly conduct the Dial-100 establishment in district Sagar there is a 'Dial-100' control room in the city called DPCR which is equipped with fully modern facilities, where exchange of information is made continuously round the clock from the SPCR. Contact is made from DPCR to FRV and jointly with the caller. In the 'Dial-100' vehicle there is vehicle and the pilot deployed there in is assisted by an institution 'Bharat Vikas Group'. There is a screen (MDT) through which 


\section{Smart Policing of Madhy Pradesh Dial-100 (Special reference to Sagar District)}

the information given by the victim/caller can be seen with telephone number. In the FRV of every police station territory a Assistant Sub-inspector (ASI) or a head constable (HC) and a constable each on 08 hr duty are every minute prepared to help the sufferer.

\begin{tabular}{|l|l|l|l|}
\hline Sr. $\mathbf{N}$ & Total Population of Sagar District & trength in Sagar & ring population by one FRV \\
\hline 01 & 2378458 & 26 & 91479.15 \\
\hline
\end{tabular}

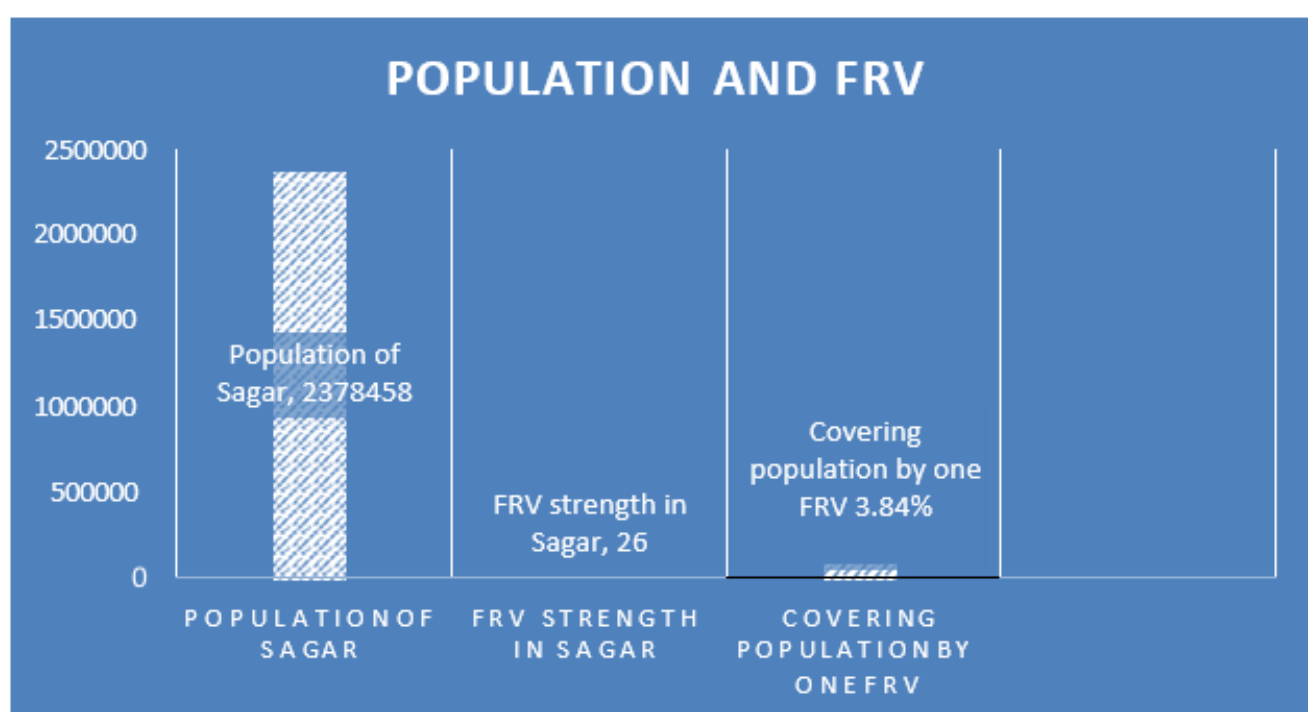

\section{THE OPPRESSED AND POLICE CONTACT-MANAGEMENT:}

As soon as a person calls on number-100, in SPCR Bhopal a non-police worker (call taker) out of the 125 technically trained ones listens to the caller very politely and as soon as the call is received, the call taker from his monitor transfers the information to the dispatcher desk. With this call the system generates automatically an INS number that calls event id through which all procedure is conducts and it can be used any time in future. On the dispatcher desk all the workers are technically trained police persons/officers. They forward the information simultaneously to concerning DPCR and FRV through CAD to MDT. From the time the call is made it takes only one to two minute to rush the information to the FRV team. As soon as the information is received the team contacts the caller's mobile number displayed on MDT, and hurried to the place of incident. After action has been taken (positive/negative) an action taken report (ATR) is filled by the Dial-100 team or by DPCR as per information by Dial- 100 team. After 24 hour a feedback on the merit or quality of police action in that event is obtained by SPCR from the caller on phone.

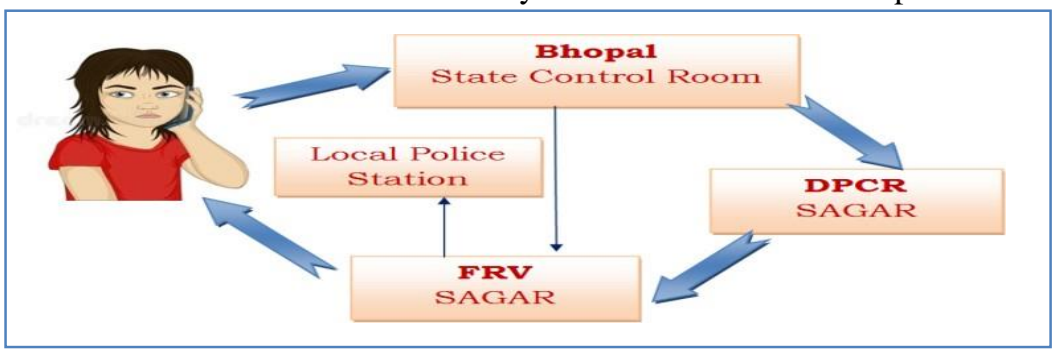

For the purpose of FRV tracking and reporting in the district there is a 'Dashboard' in the Dial-100 control room. Through this system any police officer and single point of contact (SPOC) who is Reader of all police stations and office of CSP,SDOP,ASP,SP or employee can get information of the position of any related FRV \& event by his ID and password. The duty of SPOC is to inform his officer about incidents which he receives through sms. Also he/she can prepare report. Its procedure is as follows:

- To login on the dial-100 web portal through internet.

- After login division of works is made on Dial-100 portal screen by the following points-

1. Incident Dashboard: Numeral information through caller ID.

2. FRV Dashboard: The location of FRV conduction through GPS.

3. Incident Analysis: Paces of information are GIS tagged, so that the density of in a particular place of Madhya Pradesh can be known better.

4. Telephone Directory: For the purpose of knowing the emergency services number of all officers attached to Dial-100 system. Pieces of information received from the caller are divided on two levels. First- information received under the jurisdiction of Dial100 eg. Common crimes, several crimes. At present the number of such crimes is 291 types. Second - incidents are not related to FRV called NON FRV events which are52. Their information is transferred directly to Police officer/higher officer (e. g. SDOP, 


\section{Smart Policing of Madhy Pradesh Dial-100 (Special reference to Sagar District)}

CSP, ASP, SP). Incidents informed of on dial-100 divided on the nature of events. On the basis of events, events occurred during one month are analyzed by the means of table and graph. During one month from 01 June to 01 July,2018 there are total number of reported event is 7292 in Sagar district in which there are some types are analyzed.

Table-1: ROAD ACCIDENT

\begin{tabular}{|l|l|l|l|l|}
\hline Sr. & Types of accidents & Number of accidents & Percent & Total Percent \\
\hline $\mathbf{1}$ & Single injured & 401 & $95.7 \%$ & \\
\hline $\mathbf{2}$ & Several injured & 18 & $4.2 \%$ & \\
\hline $\mathbf{3}$ & Death & 00 & $00 \%$ & \\
\hline & Total & $\mathbf{4 1 9}$ & $\mathbf{1 0 0 \%}$ & $\mathbf{5 . 7 4 \%}$ \\
\hline
\end{tabular}

By means of the present table and graph it is shown that under transport management in Sagar district maximum events $95.7 \%$ have been single accidents and road accidents contains $5.74 \%$ in total 7292 reported cases. The reason of accident is careless driving and damage road and some little mistakes as caller reported.

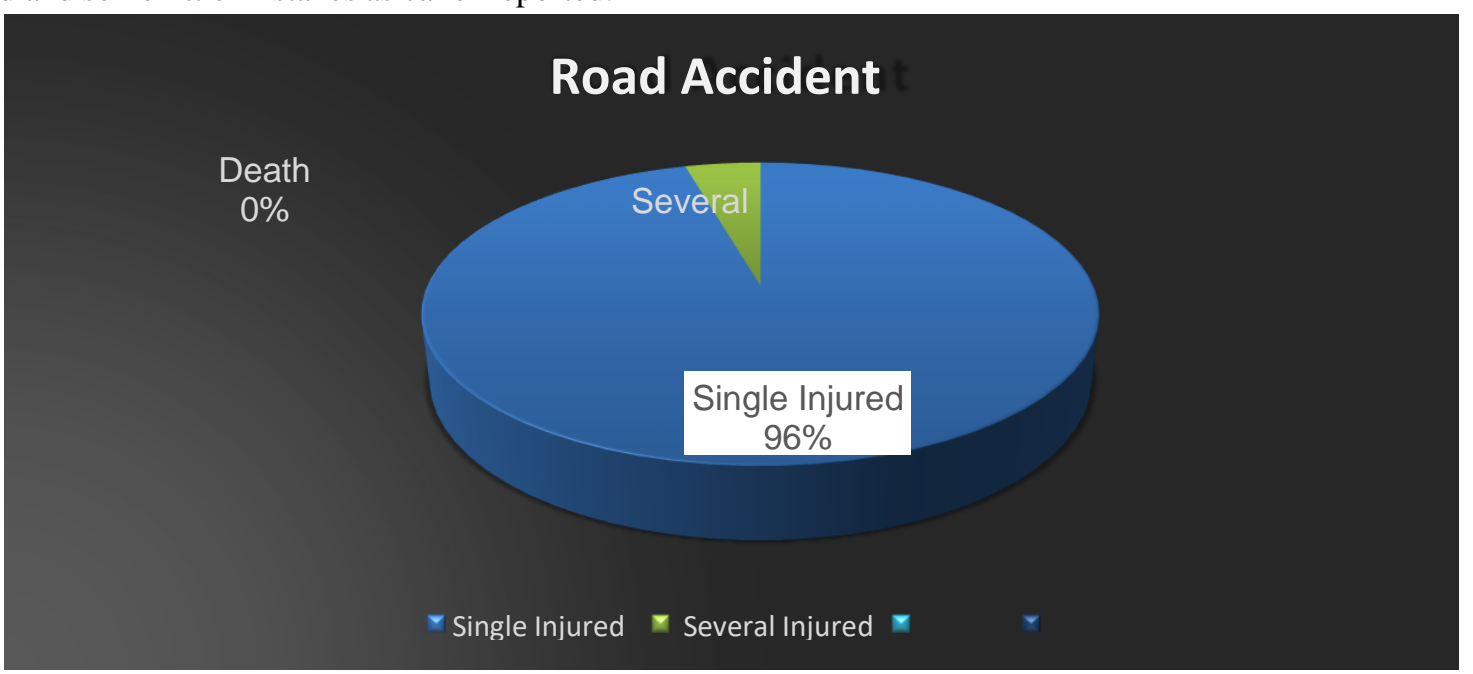

Table-2: Children Related Crime

\begin{tabular}{|l|l|l|l|l|}
\hline Sr. & Types of accidents & Number of accidents & Percent & Total Percent \\
\hline 1 & Abandoned infant & 02 & $5.7 \%$ & \\
\hline 2 & Atrocity & 06 & $17.1 \%$ & \\
\hline 3 & Bonded child & 01 & $2.8 \%$ & \\
\hline 4 & Child help line & 00 & $0 \%$ & \\
\hline 5 & Child marriage & 12 & $34.2 \%$ & \\
\hline 6 & Child trafficking & 01 & $2.8 \%$ & \\
\hline 7 & Lost child & 13 & $37.1 \%$ & \\
\hline & Total & $\mathbf{3 5}$ & $\mathbf{1 0 0 \%}$ & $\mathbf{0 . 4 7 \%}$ \\
\hline
\end{tabular}

By means of the present table and graph events related to children have been mentioned. According to the present facts during the fixed period of time maximum number of event $37 \%$ have been noted about lost children. Children related crime contains $0.47 \%$ of all data. We found that about children affairs families or guardians are unable to secure them.

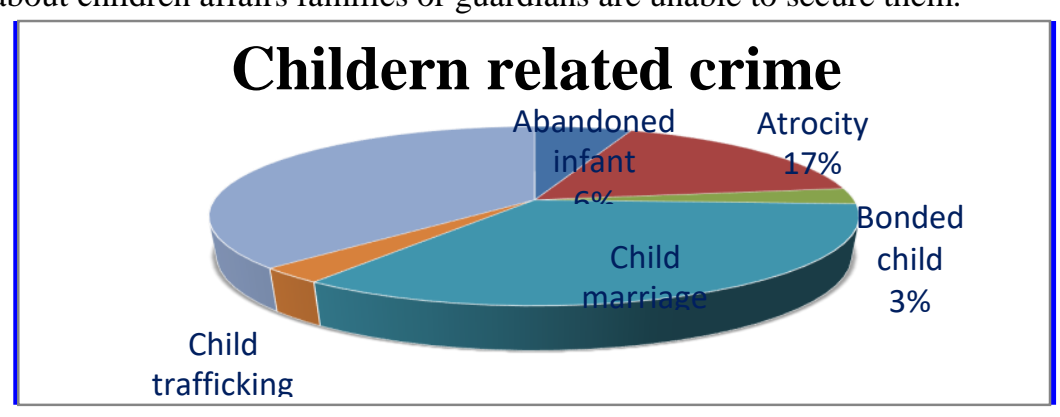


Smart Policing of Madhy Pradesh Dial-100 (Special reference to Sagar District)

Table-3: Related to Senior Citizen:

\begin{tabular}{|l|l|l|l|l|}
\hline Sr. & Types of accidents & Number of accidents & Percent & Total Percent \\
\hline 1 & $\begin{array}{l}\text { Torture to senior } \\
\text { citizen }\end{array}$ & 69 & $100 \%$ & \\
\hline & Total & $\mathbf{6 9}$ & $\mathbf{1 0 0 \%}$ & $\mathbf{0 . 9 4 \%}$ \\
\hline
\end{tabular}

In the present table events concerning old ones have been mentioned. According to the present figures during the fixed period all cases 69 have been noted about tortures of old persons.

Table-4: Miscellaneous Crime:

\begin{tabular}{|l|l|l|l|l|}
\hline Sr. & Types of accidents & Number of accidents & Percent & Total Percent \\
\hline 1 & $\begin{array}{l}\text { Altercation at public } \\
\text { place }\end{array}$ & 01 & $0.01 \%$ & \\
\hline 2 & Drivers Quarrel & 03 & $2 \%$ & \\
\hline 3 & Adulterated in fuel & 00 & $0 \%$ & \\
\hline 4 & Gambling & 71 & $25 \%$ & \\
\hline 5 & Intimidation & 130 & $46 \%$ & \\
\hline 6 & Mischief & 34 & $12 \%$ & \\
\hline 7 & Missing person & 14 & $5 \%$ & \\
\hline 8 & $\begin{array}{l}\text { Obstruct in govt. } \\
\text { duty }\end{array}$ & 05 & $2 \%$ & \\
\hline 9 & Ragging & & $0 \%$ & \\
\hline 10 & Scamming in goods & 02 & $0.1 \%$ & \\
\hline 11 & $\begin{array}{l}\text { Tree cutting in } \\
\text { illegal manner }\end{array}$ & 22 & $8 \%$ & $3.86 \%$ \\
\hline
\end{tabular}

The table no. 4 describes about miscellaneous crime reported through dial-100. As shown in the table the highest frequency of informing crime is intimidation contains $46 \%$. It includes threats to kill and threats. Following this gambling is big problem which always been one of the big social evils. The miscellaneous crime contains $3.86 \%$ of all sample.

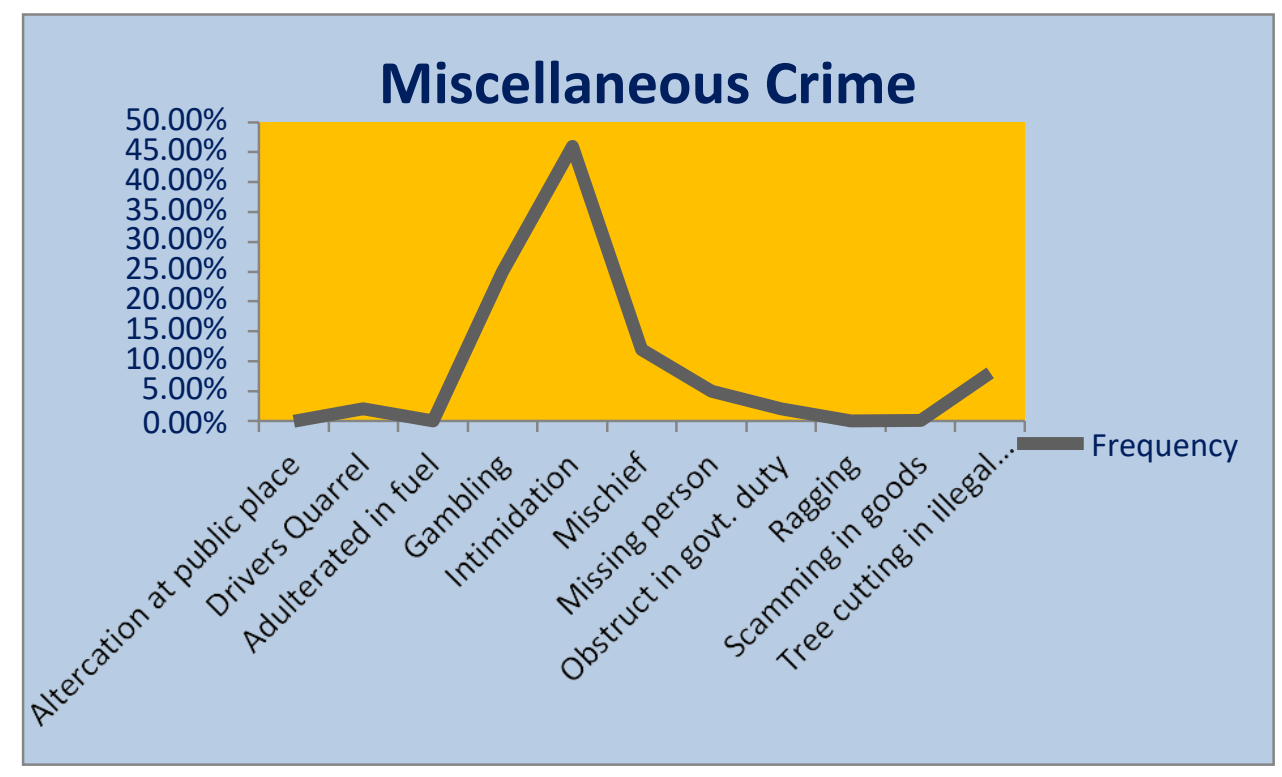


Smart Policing of Madhy Pradesh Dial-100 (Special reference to Sagar District)

Table-5 Crime body:

\begin{tabular}{|c|c|c|c|c|}
\hline Sr. & Types of Accidents & Number of Accidents & Percent & Total Percent \\
\hline 1 & $\begin{array}{l}\text { Abduction for } \\
\text { ransom }\end{array}$ & 00 & $0 \%$ & \\
\hline 2 & Acid attack & 00 & $0 \%$ & \\
\hline 3 & Dead body & 12 & $0.7 \%$ & \\
\hline 4 & $\begin{array}{l}\text { Foul smell from } \\
\text { house }\end{array}$ & 00 & $0 \%$ & \\
\hline 5 & House tress pass & 32 & $2 \%$ & \\
\hline 6 & Grievous hurt & 111 & $6 \%$ & \\
\hline 7 & Simple hurt & 1366 & $80 \%$ & \\
\hline 8 & $\begin{array}{l}\text { Kidnapping of male } \\
\text { child }\end{array}$ & 06 & $0.3 \%$ & \\
\hline 9 & Mass killing & 00 & $0 \%$ & \\
\hline 10 & Murder & 38 & $2.2 \%$ & \\
\hline 11 & Attempt to murder & 34 & $2 \%$ & \\
\hline 12 & $\begin{array}{l}\text { Beating in close } \\
\text { room }\end{array}$ & 02 & $0.1 \%$ & \\
\hline 13 & Abetment to suicide & 00 & $0 \%$ & \\
\hline 14 & Suicide & 104 & $6 \%$ & \\
\hline \multirow[t]{2}{*}{15} & Unnatural Sex & 01 & $0.05 \%$ & \\
\hline & Total & 1706 & $100 \%$ & $23.39 \%$ \\
\hline
\end{tabular}

The crime body describes about crime in which must be injured human body. The present table shows that during the fixed period the maximum events are reported on the system about of simple injury i.e. 80 percent. Following this suicide contains high ratio. Crime body contains $23.39 \%$ of all data.

Table-6 Crime related to Women:

\begin{tabular}{|c|c|c|c|c|}
\hline Sr. & Types of Accidents & Number of Accidents & Percent & Total Percent \\
\hline 1 & $\begin{array}{l}\text { Bad touch to } \\
\text { women }\end{array}$ & 05 & $0.5 \%$ & \\
\hline 2 & $\begin{array}{l}\text { Women beating to } \\
\text { husband }\end{array}$ & 06 & $0.6 \%$ & \\
\hline 3 & Beating to wife & 192 & $19.7 \%$ & \\
\hline 4 & Domestic violence & 131 & $13.4 \%$ & \\
\hline 5 & Dowry death & 00 & $0 \%$ & \\
\hline 6 & Torture for dowry & 10 & $1 \%$ & \\
\hline 7 & Eve teasing & 49 & $5 \%$ & \\
\hline 8 & Family disputes & 480 & $49.3 \%$ & \\
\hline 9 & $\begin{array}{l}\text { To compel for flesh } \\
\text { trade }\end{array}$ & 00 & $0 \%$ & \\
\hline 10 & $\begin{array}{l}\text { Feticide } \\
\text { (illegal abortion) }\end{array}$ & 00 & $0 \%$ & \\
\hline 11 & $\begin{array}{l}\text { Kidnap to female } \\
\text { child }\end{array}$ & 23 & $2.3 \%$ & \\
\hline 12 & $\begin{array}{l}\text { Lewd call/e-mail to } \\
\text { women }\end{array}$ & 38 & $3.9 \%$ & \\
\hline
\end{tabular}


Smart Policing of Madhy Pradesh Dial-100 (Special reference to Sagar District)

\begin{tabular}{|l|l|l|l|l|}
\hline 13 & $\begin{array}{l}\text { Lewd comment to } \\
\text { women }\end{array}$ & 09 & $0.9 \%$ & \\
\hline 14 & Murder to women & 00 & $0 \%$ & \\
\hline 15 & Obscene gestures & 00 & $0 \%$ & \\
\hline 16 & Prowling to women & 02 & $0.2 \%$ & \\
\hline 17 & Rape & 04 & $0.4 \%$ & \\
\hline 18 & Attempt to rape & 11 & $0.1 \%$ & \\
\hline 19 & $\begin{array}{l}\text { Scandalous video } \\
\text { of women }\end{array}$ & 01 & $0.1 \%$ & \\
\hline 20 & Sexual harassment & 01 & $1.1 \%$ & \\
\hline 21 & $\begin{array}{l}\text { Wanton women } \\
\text { found }\end{array}$ & 11 & $100 \%$ & $13.34 \%$ \\
\hline & Total & 973 & & \\
\hline
\end{tabular}

By means of the present table events related to women have been mentioned. According to the present facts during the fixed period of time maximum number of event 49.3 percent have been noted about family disputes in family with women. Following this the high crime reporting is about beating to wife. Women related crime contains $13.34 \%$ of all sample.

\section{FRV team as a Spot Counselling:}

As soon as the information is received about incident place and victim, FRV team moves towards the place. During this the team constantly is connect with the victim through the phone call. As soon as reached the incident place FRV team first contacts the victim and if emergency, takes victim to the hospital. If not so then team first of all listen carefully both sides (caller and non-caller) and as possible tries to reconcile through counselling (e. g. Misbehave, quarrel, and alcohol case). In disobedience of any side or in heinous crime team comes to respective police station with both parties and hand over the matter to SHO. According to circumstances team also lodges zero FIR at incident spot. Before November 2015 these type police services were only in dream in India but present scenario iswitness that how smart policing is on base in front of over 75 million eyes.

\section{FRV team as a Surveillance and Vigilance:}

In the district all FRV stop point is called nodal point. From nodal point it moves the events. The travelling distance between events it gathers information all body which may be harmful for society. During action taking on crime body team informs about incident to police control room and officers. In each 24 hour it has three time ROUND EVENT, each having 02 hour. In this way the team works as surveillance and vigilance.

\section{CERTAIN PROBLEMS ATTACHED TO THE CONDUCTION OF DIAL-100 AND SUGGESTIONS:}

In the present part the taxis in the police department, their way of work and the reaction of the victim/caller who has used dial-100 have been dealt with; also solutions to solve the problems have been suggested. Dial-100 was started with the purpose of usher in immediate help to the victim in moment of disaster misery and to eradicate crimes to the maximum possible extent. The major portion of population in Sagar district is that of rural people. The police side contacting the victim first of all is FRV staff. In addition to take proper action at incident place, FRV takes the victim as well as the accused to the hospital. Certain of problems coming on the way of management of the whole procedure and their solution have been dealt as follows-

* Generally people dials 100 number on mere in front of trifle eg. Someone spread his cot in front of other person's house, the draining down of water from someone's roof on his neighbour's side and so on and so for etc. By these reasons the FRV becomes unable to reach cooperatively serious event spot in time. So citizen should act sensibly.

* In the SPCR many callers get engaged in personal talk with the call taker. People specially the youth should behave like responsible and civilized citizen.

* In incidents of fire FRV without any doubt gets to the spot in time; the fire Brigade staffs however reach only after the fire has taken fierce shape. The reason might be fire vehicle, lack of water or multiplicity of occurrence. Keeping view such probabilities, therefore government must pay attention and people ought to help the victim on humanitarian ground.

* Owing to excessive political interference in police proceedings at several times, the real victim remains deprived of help and relief. Police personals in uniform play their role in apprehending a human being breaking law in his own human society and reestablishing him in the society as correct. Therefore, everyone is expected to co-operate unbiasedly with another.

* Sometimes complainants make their complaints in such an exaggerated way as could cause the accused (uncomplaining person) 


\title{
Smart Policing of Madhy Pradesh Dial-100 (Special reference to Sagar District)
}

to bear a lot of police torture. Everyone must refrain from such activities it quince since may be recoil agony to himself in return. Some youth who are at a green age, using well socio-friendly of dial1 100 service with whatsapp. This system created strong reliability between the police and public relationship. Dial-100 whatsapp system not only provides the information of incidents but also evidence of crime scene as form of video, photograph. In Sagar daily approx. 200 events receiving and sometime it records more than 760 but all cases close within 24 hour by ATR.

\section{CONCLUSION AND SUBSTANCE:}

Madhya Pradesh has been called 'Island of Tranquility' because generally the position of Law \& Order here is much better than other neighbor states; But now days system demands reformation with modernization. It is fact that where is dense population; possibilities of crime occurrence will more. The above analysis and discrimination aims at presenting a scientific and factual position of the responsibility of the police and their problems as well as their way of working. Police persons are the person of our own society who are entrusted with lawful responsibilities. The relationship of police persons with the public is amicable. In order to make the management are the more flexible and effective, in Sagar 12 ultramodern FRV bikes have been recently deployed which are equipped with MDT. For their effective and amicable action the Madhya Pradesh dial-100 has been bestowed with several national and international awards eg. Geospatial world Excellence Award, Hexagon Safety \& Infrastructure Icon Award-2017. It adorned with Smart Policing Award in May 2017 by FICCI and so on. On the one occasion ADG (TC) Shri Anvesh Manglam said "We have worked out the system as people don't turn up to police stations with their complaints due to the lackluster response of law enforcers. Usually, poor and marginalized people first approach some influential person to contact police," Undoubtedly this is much better towards Desh Bhakti-Jan Seva.

\author{
Abbreviation: \\ SPCR: State Police Control Room \\ DPCR: District Police Control Room \\ FRV: First Response Vehicle \\ MDT: Mobile Data Terminal \\ GIS: Geographical Information System \\ CAD: Computer Aided Dispatch \\ GPS: Global positioning System \\ ATR: Action Taken Report
}

\section{REFERENCE}

1) Newburn, T. (2017) Criminology, NewYork, Routledge.p636, 640.

2) https://www.patrika.com/bhopal-news/bhopal-new-scheme-for-dial-100-soon-7759/

3) http://www.grantthornton.in/insights/case-study/dial-100-project-madhya-pradesh/

4) http://sagar.nic.in/HTMLPage.htm

5) Saxena, N. (2018, November 20). Pahle se bahut behtar hain halaat. Navduniyan, p. 10.

6) Saxena, G. (2018, November 20). Hr apradh me hm aage kyun?. Navduniyan, p. 10.

7) https://economictimes.indiatimes.com/news/politics-and-nation/madhya-pradesh-police-to- launch-state-level-dial-100emergency-service/articleshow/45247769.cms

8) https://www.dailypioneer.com/2015/state-editions/cm-inaugurates-dial-100-scheme-on-mp- foundation-day.html

9) https://www.bhaskar.com/mp/sagar/news/now-dial-100-directly-in-the-fleet-of-police- 053510-3139117.html

10) https://www.mppolice.gov.in/en

11) Saxena, A. (Editor). Dial-100 Nirdeshika, Police Headquarter (telecom), Bhopal, M.P.

12) Upadhyay, R. (2018) Dial-100 ki vyastha, sanchalan v karya me aane wali samasyayen evm upyogita (Sagar jile ke vishesh sandarbh me), Sagar, M.P.

13) https://www.youtube.com/watch?v=QtSC-CY9Xx4

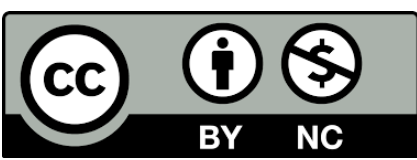

There is an Open Access article, distributed under the term of the Creative Commons Attribution - Non Commercial 4.0 International (CC BY-NC 4.0)

(https://creativecommons.org/licenses/by-nc/4.0/), which permits remixing, adapting and building upon the work for non-commercial use, provided the original work is properly cited. 